\title{
KOMUNIKASI KELUARGA \\ (STUDI KASUS KOMUNIKASI INTERPERSONAL SUAMI ISTRI DALAM PROSES CERAI DI KANTOR URUSAN AGAMA KECAMATAN GAMPING)
}

\author{
Etika Sari \\ Program Studi Komunikasi Konseling Islam \\ Program Pasca Sarjana \\ Universitas Muhammadiyah Yogyakarta \\ E-mail: etikasari2108@gmail.com
}

\begin{abstract}
Abstrak
Penelitian ini dilakukan bertujuan untuk mengetahui proses komunikasi interpersonal pada pasangan suami istri dalam proses cerai dan untuk mengetahui cara penyelesaian konflik yang dilakukan oleh pasangan suami istri dalam proses cerai. Metode penelitian ini menggunakan pendekatan kualitatif, dengan wawancara mendalam. Objek penelitian di KUA kecamatan Gamping, sebagai subjek adalah empat pasangan suami dan istri. Hasil penelitian ini menunjukan bahwa proses komunikasi interpersonal pada pasangan suami istri ini bermula pada prasangka, bungkamnya pasangan suami istri yang tidak di diskusikan setiap masalah baik hutang-piutang maupun masalah lain, tidak adanya dialog secara terbuka dan keegoisan pasangan yang merasa paling benar dan tidak mau saling menerima pendapat setiap pasangan. Penyelesaiaan yang dilakukan pada pasangan suami istri ini menemukan jalan win-lose solution dan win-win solution. Penyelesaian konflik yang berjalan secara win-win solution apabila dilakukannya mediasi sebagai penengah masalah pasangan yang dilakukan oleh penyuluh di KUA Gamping.
\end{abstract}

Kata kunci: Komunikasi Interpersonal, Pasangan Suami Istri, Perceraian

\begin{abstract}
The research is conducted for two motives. Firstly, in order to find out how a husband and a wife communicate each other in divorce processing. Secondly, to find out what way could be the best problem solving the counterpart able to do in their divorce processing. The data collection method of the research is qualitative approach, the technique is collecting the data by observating, deep interviewed and also documantation. We have four counterparts as the objects of this reseach in KUA Gamping. The result of this research demonstrated that interpersonal communication process of counterpart is biggining with a prejudice, one of them soundless to tell what problem that comes to their household such as debts and receivables even any other problem which is bad to conflict, no open minded conversation to each other, their egos with the result that guesting she or he is the right one so every opinion really unacceptable for each other. Secondly, problem solving is found out of these counterparts are win-lose solution and win-win solution. Win-win solution is applying if there a mediation as the madiator between husband and wife to help them overcome thir problem. The mediator could be counselor of KUA Gamping.
\end{abstract}

Key words: interpersonal communication, the counterparts, divorcement

\section{Info Artikel}

Diterima Agustus 2017, disetujui September 2017, diterbitkan Desember 2017

Dipublikasikan Oleh: Program Studi Bimbingan dan Konseling 


\section{PENDAHULUAN}

Kehidupan dalam rumah tangga ibarat sebuah perjalanan sepasang suami istri yang penuh dengan suka dan duka. Akan tetapi perjalanan menuju sebuah kehidupan yang bahagia tentu bukan hal yang mudah untuk menyatukan cita-cita bersama. Untuk menciptakan sebuah rumah tangga yang harmonis akan banyak kendala yang dihadapi pada pasangan suami istri. Kendala terbesar dalam sebuah hubungan adalah komunikasi. Banyak masalah rumah tangga tidak dapat teratasi dengan baik karena komunikasi yang tidak efektif.

Keterampilan

komunikasi interpersonal saat ini sangat penting dalam kesuksesan sebuah hubungan. Komunikasi interpersonal dapat diartikan sebagai interaksi yang terjadi antara seseorang dengan orang lain yang berlangsung secara dialogis. Walaupun, suasana komunikasi dialogis tidak selalu sesuai yang diharapkan bahwa akan selalu terjadi kesetaraan dan saling memberi menerima secara adil. Komunikasi sebagai cara untuk mendekatkan diri pada lawan bicara terutama dalam sebuah keluarga.

Dalam hubungan komunikasi interpersonal sangat dibutuhkan sikap sabar, pengertian, jujur, saling percaya, dan tidak mudah berprasangka buruk pada pasangan. Oleh karena itu kecerdasan emosi pada setiap pasangan sangat penting. Devito dalam bukunya menyatakan komunikasi efektif akan menciptakan hubungan antara manusia yang ditekankan pada kualitas keterbukaan, empati, sikap mendukung, sikap positif dan keintiman. Banyak ditemukan pada penelitian terdahulu bahwa hasil menunjukan kualitas komunikasi interpersonal pada pasangan suami istri sangat membutuhkan keterbukaan dan saling mendukung pada pasangan suami istri. Akan tetapi sebaliknya jika terdapat ketidakjujuran, kecemburuan, dan perselisihan yang justru berdampak pada perceraian.

Kasus perceraian kini tidak dapat dihindari yang meningkat setiap tahunnya. Angka perceraian di kabupaten Sleman Yogyakarta mengalami hal yang relatif naik turun dalam tiga tahun belakangan. Dapat dilihat dalam tabel sebagai berikut:

Tabel 1. Data Perceraian di Kabupaten Sleman

\begin{tabular}{|c|c|c|c|c|}
\hline No & Tahun & $\begin{array}{c}\text { Kasus } \\
\text { Gugat }\end{array}$ & $\begin{array}{c}\text { Kasus } \\
\text { Talak }\end{array}$ & Jumlah \\
\hline 1 & 2014 & 1081 & 469 & 1550 \\
\hline 2 & 2015 & 1045 & 464 & 1510 \\
\hline 3 & 2016 & 1083 & 466 & 1549 \\
\hline
\end{tabular}

Sumber : Data diolah oleh peneliti

Tabel 1 di atas dapat dilihat bahwa jumlah kasus pada tahun2014 kasus perceraian yang masuk ke pengadilan agama dengan 1550 kejadian, dengan kasus 5108 kasus gugat cerai, dan 469 kasus talak. 2015 Kasus perceraian yang masuk ke Pengadilan Agama Sleman berjumlah 
1.510 kejadian cerai talak sebanyak 465 dan cerai gugat 1.045 kasus. Sementara pada tahun 2016 jumlahnya meningkat menjadi

Tabel 2. Data Perceraian di Kecamatan Gamping

\begin{tabular}{|c|c|c|c|c|}
\hline No & Tahun & $\begin{array}{c}\text { Kasus } \\
\text { gugat } \\
\text { cerai }\end{array}$ & $\begin{array}{c}\text { Kasus } \\
\text { talak }\end{array}$ & Jumlah \\
\hline 1 & 2014 & 20 & 18 & 38 \\
\hline 2 & 2015 & 16 & 24 & 40 \\
\hline 3 & 2016 & 30 & 16 & 46 \\
\hline
\end{tabular}

Sumber : data dioleh oleh peneliti

Data yang akan dilakukan penelitian di Gamping juga demikian meningkat dalam tiga tahun terakhir baik jumlah gugat cerai maupun talak, pada tahun 2014 berjumlah 38 dengan gugat cerai 20 dan talak berjumlah 18 kasus, pada tahun 2015 berjumlah 40 dengan gugat cerai 16 kasus, dan talak 24 kasus, pada tahun 2016 berjumlah 46, dengan kasus gugat cerai 30 dan talak 16 kasus. Sedangkan 2017 yang mulai Januari hingga Mei terdapat 8 kasus dengan gugat cerai 6 kasus dan talak 2 kasus.

Data yang ada bahwa gugat cerai paling tinggi dibanding cerai talak. Dari hasil rekap yang terdata pada pengadilan agama banyak faktorfaktor terjadinya perceraian dan yang paling tinggi penyebab utama adalah tidak ada keharmonisan, kedua tidak ada tanggung jawab, ketiga ekonomi, keempat ganguan pihak ketiga, kelima krisis akhlak, keenam kekerasan dalam rumah tangga baik secara pisik maupun psikis, dan selanjutnya cemburu.

Faktor-faktor yang tersebut menunjukan bahwa ketidakharmonisan menjadi pemicu yang mendasar dalam rumah tangga. Oleh karena itu untuk membangun koharmonisan sangat penting komunikasi yang efektif antara suami istri. Menurut Joseph Devito seorang pakar komunikasi menyebutkan ada lima kualitas umum yang dipertimbangkan untuk efektivitas sebuah komunikasi. Lima ciri umum komunikasi yang dimaksud adalah keterbukaan, saling mendukung, bersikap posotif, memahami orang lain dan empati.

Keunikan penelitian ini adalah membahas tentang komunikasi interpersonal pasangan suami istri yang akan cerai akibat komunikasi yang tidak efektif dan maksimal dalam sebuah hubungan yang dapat memunculkan konflik yang akan berujung pada sebuah perceraian.

\section{METODE PENELITIAN}

Kajian tentang komunikasi interpersonal pada pasangan suami istri yang akan cerai di Kantor Urusan Agama Gamping ini bersifat lapangan (field research). Penelitian akan menggunakan metode kualitatif. Penentuan subyek penelitian dilakukan berdasarkan informan pada pasangan suami istri yang terdiri pada 4 pasangan suami istri yang dalam proses cerai. Adapaun teknik pengumpulan data yaitu berupa 
wawancara mendalam, observasi dan dokumentasi.

\section{HASIL DAN PEMBAHASAN}

Setelah data yang diperoleh terkumpul lengkap, maka selanjutnya penulis akan melakukan analisis kualitiatif diskriptif untuk mengetahui keterkaitan atas teori dan data yang diperoleh, pembahasan ini akan menguraikan hasil penelitian tentang Komunikasi Interpersonal pada suami istri yang bermasalah di KUA kecamatan Gamping dengan pasutri dua talak dan dua gugat cerai, adapun yang dimaksud dengan proses komunikasi interpersonal bertujuan untuk mencapai kepentingan bersama, saling pengertian antara kedua belah pihak dalam proses komunikasi, maka berikut keterangan penelitian yang di lakukan pada pasutri di kecamatan Gamping.

\section{Informan Pasutri}

a. Pasangan A dan B awal berjumpa saat sama-sama masih kuliah di Yogyakarta. A yang lulus dari UGM jurusan Arsitek memberanikan diri untuk menikah dengn B yang saat itu masih kuliah semester dua. B akhinya memutuskan berhenti kuliah karena melahirkan. B bekerja sebagai ibu rumah tangga dan A bekerja sebagai kontraktor. Pernikahan mereka berjalan selama 17 tahun dan memiliki empat putri. Pernikahan mereka kini tidak harmonis, disebabkan karena kecurigaan A yang menuduh $\mathrm{B}$ telah selingkuh dengan Satpam di tempat anaknya sekolah. A kini pergi meninggalkan B selama empat tahun tanpa lahir batin, sehingga $B$ melakukan gugat cerai pada A yang sebelumnya A juga telah menakalak B sebelum pergi meninggalkan B.

b. b. Pasangan $\mathrm{C}$ dan $\mathrm{D}$ adalah keluarga yang telah menempuh rumah tangga selama 20 tahun. Mereka memiliki tiga anak yang telah dewasa. D merasa cemburu kepada anak-anaknya karena C tidak berlaku adil kepada $\mathrm{D}$ dan anak-anaknya. Sehingga hal ini menimbulkan masalah yang berkepanjangan sampai D menggugat $\mathrm{C}$ di KUA kecamatan Gamping.

c. Pasangan E dan F bertemu atas ketidaksengajaan kerena seringnya bertemu di warung milik orang tua F hingga berjodoh atas restu kedua pihak keluarga. Perbedaan usia 12 tahun tidak menjadi penghalang untuk berumah tangga. Rumah tangga mereka telah berjalan selama tujuh tahun dan memiliki dua putri yang masih belia. Rumah tangga yang terbilang belum lama ini mengalami masalah dalam hal ekonomi, bahkan $\mathrm{F}$ kini pergi meninggalkan E dan anak-anaknya dengan hutang piutang yang belum lunas.

d. Pasangan $\mathrm{G}$ dan $\mathrm{H}$ bertemu saat di kampus mereka kuliah. G sebagai 
senior dan $\mathrm{H}$ junior dengan jurusan yang sama yaitu Psikologi. Setelah keduanya menyelesaikan pendidikannya mereka pun menikah dan tinggal dengan mertua. Kendati demikian, pernikahan mereka tidak direstui oleh orang tua $\mathrm{G}$ walaupun mereka tinggal bersama. Pernikahan ini tidak berjalan lancar karena adanya orang ketiga dalam rumah tangga mereka. Sehingga menimbulkan pertikaian yang tidak kunjung selesai. Pertengkaran yang hampir tiap hari terjadi ini menyebabkan $G$ menalak $\mathrm{H}$.

\section{Proses Komunikasi interpersonal suami istri dalam proses cerai}

Proses komunikasi adalah transfer informasi atau pesan dari pengirim pesan sebagai komunikator dan kepada penerma sebagai komunikan. Proses komunikasi tersebut bertujuan untuk mencapai saling penegrtian antara kedua pihak terlibat dalam proses komunikasi. Proses komunikais dapat berjalan secara efektif apabila adanya keterbukaan, empati, saling mendukung, sikap positif, dan kesetaraan, maka berikut keterangan penelitian yang dilakukan pada pasutri di KUA kecamatan Gamping.

a. Keterbukaan

Kualitas keterbukaan mengacu pada kejujuran seseorang pada pasangannya. Orang yang diam, tidak kritis dan tidak menganggap pada umumnya merupakan hal yang pasif dalam berkomunikasi. Tidak ada yang lebih buruk daripada ketidakacuan. Keterbukaan dalam hal komunikasi tidak hanya menyangkut keyakinan, akan tetapi melibatkan perasaan seperti kecemasan, harapan, kebanggaan, kekecewaan pada diri seutuhnya. Dalam komunikasi perlu mengembangkan sikap terbuka, sehingga dapat menimbulkan rasa percaya diri pasangan. Karena tanpa keterbukaan akan timbul sikap saling curiga dan tidak termotivasi untuk dapat terbuka pada pasangan.

b. Empati

Empati sebagai kemampuan seseorang untuk mengetahui apa yang sedang dialami orang lain pada suatu saat tertentu. Orang yang empati mampu memahami motivasi dan pengalaman orang lain, perasaan dan sikap mereka, serta harapan dan keinginan mereka untuk masa mendatan. Pengertian empati akan membuat seseorang lebih mampu menyesuaikan komunikasinya. Rasa empati akan mampu untuk menyampaikan pesan dengan cara dan sikap yang akan memudahkan penerima pesan penerimanya.

c. Sikap mendukung

Sikap mendukung yang bersedia mendengarkan pasangan dengan sikap yang suportif dan spontan dalam berkomunikasi dan 
teus terang serta terbuka dalam mengutarakan pikiranya.

d. Sikap positif

Sikap positif adalah perasaan positif untuk situasi komunikasi pada umumnya yang sangat penting untuk interaksi yang efektif. Reaksi yang negatif dalam berkomunikasi membuat pasangan merasa terganggu dan komunikasi dengan segera akan terputus. Sikap positif dapat dikatakan sebagai dorongan menghargai keberadaan dan pentingnya orang lain atau pasangan. Dorongan positif mendukung citra pribadi menjadi merasa lebih baik, sebaliknya dorongan negatif akan bersifat menghukum dan menimbulkan kebencian.

\section{e. Kesetaraan}

Suatu hubungan antarpribadi pentingnya kesetaraan, sebab ketidaksependapatan dan konflik lebih dilihat sebagai upaya untuk memahami perbedaan yang pasti terjadi pada setiap pasangan. Kesetaraan tidak mengharuskan menerima dan menyetujui begitu saja semua perilaku verbal dan nonverbal pada pasangan. Kesetaraan berarti kita menerima pasangan sebgai penghargaan positif yang tidak bersyarat kepada pasangan.

Hasil menunjukan pada pasangan pertama, yaitu A dan B menunjukan tidak adanya keterbukaan satu sama lain disaat terjadinya masalah. Pasutri ini justru menghindari masalah tanpa diselesaikan dengan baik. Awal kecurigaan suami yang menuduh istri selingkuh ini menimbulkan pertengkaran yang berlarur-larut. Suami yang lebih menyebarkan kecurigaanya kepada anak-anak dan keluarga dibanding memilih mendiskusikan akar masalah pada istrinya.

Hal ini tentu karena tidak adanya keterbukaan pasangan saat terjadiya masalah. Sejak awal untuk menciptakan komunikasi efektif pada pasangan tentu bukan hal yang mudah, rasa empati yang terjadi pada pasangan ini hanya terlihat pada istri yaitu menunjukan rasa empati dengan membantu suami yang sedang dalam masa-masa sulit dalam pekerjaannya mengalami kebangkutan. Istri yang membatu suami dengan berjualan pusla justru tidak di dukung oleh suami sehingga menimbulkan kecurigaan suami terhadap istrinya bahwa B selingkuh. Jauh dari sikap positif yang seharusnya, justru yang ditunjukan adalah sikap negatif pada pasangan. Kesetaraan pada paangan ini juga tidak menemukan jalan tengah, karena munculnya keegoisan satu sama lain yang merasa samasama benar dan tidak ada untuk mengalah demi kepentingan bersama, sehingga sangat sulit untuk saling memahami setiap pasangan.

Hasil dari pasangan kedua yaitu C dan D, menunjukan tidak efektif dalam komunikasi antara istri dan suami, ibu dan anak dan ibu mertua 
dengan menantu. Hubungan keluarga bisa terjadi tidak harmonis karena kurangnya pengertian dan pemahaman pribadi satu sama lain sehingga terjadi kesalapahaman yang berlanjut pada kecemburuan satu sama lain dalam keluarga. masalah pasangan ini bermula pada prasangka istri yang tidak diberlakukan secara adil oleh suaminya dengan anak-anaknya.

Prasangka yang berlarut sampai pada sebuah gugatan istri ke suami. Prasanga istri yang menganggap suami sebagai orang yang tidak jujur, tidak terbuka dan cemburu kepada anak-anaknya. Istri yang memiliki prasangka tersebut tentu bukan hal yang baru, hanya saja tuntutan yang dilakukan istri juga tidak sebanding dengan kewajiban D sebagai istri kepada C. kedua pasangan ini justru tampak menghindari masalah dan tidak didiskusikan, sehingga bungkamnya pasanggan ini jauh dari keterbukaan satu sama lain. Jika hanya hanya menuntut dan tidak ada yang memulai untuk terbuka tentu tidak akan terjadi komunikasi yang efektif seperti yang diharapkan.

Empati dan saling mendukung tentu hal yang tidak dapat dipisahkan, hanya saja pasangan ini tidak membangun hubungan dengan rasa empati dan saling mendukung yang ada justru berbanding terbalik, istri yang banyak menuntut sedangkan suami memilih lebih banyak diam. Keduanya tidak ditemukan sikap positif, sedangkan kesetaraan di tunjukan pada istri yang lebih mendominasi suami, tentu ini bukan kesetaraan pada pasangan.

Hasil dari pasanganketigayaitu E dan $\mathrm{F}$ menunjukan bahwa seorang istri yang berusaha berkali-kali tidak jujur pada suaminya. Ketidakjujuran istri adalah kebalikan dari keterbukaan pada pasangan, walaupun demikian suami berusaha untuk tetap mengayomi istrinya untuk bisa berubah. Rumah tangga yang berjalan selama tujuh tahun kini mengalami kesulitan ekonomi. E hanya seorang bersih-bersih di pasar Gamping, istri yang awalnya punya usaha warung makan juga mengalami kebangrutan dan tutup.

Hutang yang banyak membuat $\mathrm{F}$ meninggalkan suami dan anakanaknya yang masih kecil. F yang masih berusia 24 tahun tega meninggalkan anak-anaknya, tentu hal tersebut jauh dari rasa empati. E merasa kepikiran istri dan anakanaknya juga mengalami sakit maag akut setalah kepergian istrinya. Tidak adanya sikap saling mendukung satu sama lain membuat hubungan pasangan ini bagaikan telur di ujung tanduk.

Istrinya kurang menghargai suami sebagai kepala rumah tangga dan meninggalkan kewajiban seorang itu yang seharusnya mengasuh anakanak. sikap positif dan kesetaraan pada pasangan ini terbilang sudah tidak ada lagi, padahal rumah tangga dari pasangan ini terbilang belum cukup lama. 
Hasil dari pasangan keempat yaitu $\mathrm{G}$ dan $\mathrm{H}$ memiliki masalah sejak awal dalam menjalin rumah tangga yaitu tidak ada restu dari ibu mertua. Kendati demikian, rumah tangga mereka telah berjalan selama delapan tahun dan memiliki seorang putri. Awal permasalah pasangan ini adalah $\mathrm{G}$ yang selingkuh saat $\mathrm{H}$ sakit parah di Rumah Sakit selama setahun. Karena membutuhkan biaya yang tidak sedikit, $\mathrm{G}$ meminta tolong pada teman dekatnya, akan tetapi hubungan mereka berlanjut hubungan yang tidak seharusnya yaitu perselingkuhan. Setelah H sembuh, G merasa bersalah dan mengakui atas perbuatannya yang salah.

Keterbukaan suami ini justru menjadi dampak keributan antara $G$ dan $\mathrm{H}$, hingga keluar ucapan talak pada H. walaupun demikian, hubungan ini masih dalam proses memperbaiki rumah tangga mereka. Sehingga rasa empati, saling mendukung, sikap positif dan kesetaraan dapat di bangun. Memperbaiki diri dan menerima pendapat pasangan dan mempercayai pasangan adalah kunci rumah tangga yang dapat berjalan harmonis.

\section{Penyelesaian Konflik Suami Istri Dalam Proses Cerai}

Konflik merupakan sebuah situasi perselisihan atau pertentangan dimana tindakan salah satu pihak berakibat menghalangi, menghambat, atau menggangu pihak lain. Konflik yang terjadi pada pasangan suami istri ini karena tidak efektifnya komunikasi yang terjadi dalam hal keterbukaan, empati, saling mendukung, sikap positif, dan kesetaraan sehingga konflik yang terjadi berakhir pada gugatan dan talak.

Teori yang digunakan adalah konflik berdasarkan pelanggaran/tanpa pelanggaran.

Bentuk-bentuk kesepakatan dalam perkawinan antara lain terbentunya aturan-aturan dalam rumah tangga. Aturan ini disepakati apa yang boleh dan tidak boleh. Namun demikian tidak jarang, aturan dilanggar oleh mitra dan akhirnya mencul. Metts, menyatakan bahwa konflik berdasarkan pelanggaran memiliki tiga karakteristik kunci yaitu fokus, mencolok mata, dan konsekuensi.

Hal tersebut menjelaskan tentang peraturan seperti menghargai kebebasan pasangan, mengingat kejadian-kejadian yang telah lalu mengenai pelanggaran, mempertimbangkan pasangan dengan pasangan, serta dampak pada pelanggar dalam hubungan masa depan. Bentuk pelanggaran adalah kunci penentu hubungan akan berlanjut atau tidak. Berikut penyelesaian konflik yang dilakukan oleh pasangan suami istri sebagai berikut:

Hasil pada pasangan suami istri yang pertama adalah konflik yang terjadi adalah pelanggaran atas menghargai seorang yang menuduh selingkuh. Hal tersebut karena kurang adanya keterbukaan/kejujuran serta 
sifat yang mendominasi sebagai suami bahwa dialah yang benar. Sehingga penyelesaian pada konflik yang dihadapi adalah gugatan cerai yang diajukan istri ke suaminya.

Hasil pada pasangan suami istri yang kedua adalah konflik atas dasar cemburu dan masalah kurang perhatian terhadap pasangan sehingga terjadinya kesalapahaman. Namun setalah terjadinya mediasi yang dilakukan pada pasangan ini keduanya dapat rujuk kembali dengan adanya keterbukaan yang di bangun satu dengan yang lain.

Hasil pada pasangan suami istri yang ketiga adalah masalah ekonomi yang belum terselesaikankan. Sehingga konflik ini dikatakan sebagai pelanggaran yang dilakukan oleh istri yang berusaha menyembunyikan. Sehinga konsekuensi yang terjadi pada pasangan ini lebih berdampak pada ketidaksiapan setiap pasangan untuk mengulang hal-hal yang telah terjadi. Karena penyelesaian yang dilakukan oleh kedua bela pihak belum tentu berjalan sesuai yang diharapkan. Sehingga dalam kasus ini pasangan ini masih dalam penyelesaian intopeksi diri.

Hasil pada pasangan suami istri yang keempat adalah kedua pasangan ini mampu menciptakan win-win solution sebab keduanya mampu mengambil pelajaran dari peristiwa yang dialami, mereka mengakui kesalahan, dan memulai untuk memperbaiki hubungan dengan sikap saling mendukung dan kepercayaan yang ternama satu sama lain.

\section{KESIMPULAN}

Berdasarkan hasil penelitian tentang Komunikasi Interpersonal pada pasangan yang akan cerai (studi kasus di KUA kecamatan Gamping) dengan pengumpulan data baik dalam observasi langsung, wawancara dan penelitian dokumen kemudian dilakukan analisis dapat di tarik beberapa kesimpulan sebagai berikut:

1. Proses komunikasi interpersonal pada pasangan suami istri yang akan cerai mula-mula terjadi prasangka/kecurigaan pasangan yang menuduh tanpa bukti yang jelas, bungkamnya pasangan suami istri yang tidak di diskusikan setiap masalah baik itu masalah hutang piutang atau yang lainnya, keegosian pasangan yang merasa paling benar dan tidak mau saling menerima pendapat setiap pasangan. Hal tersebut sebagai pemicu proses komunikasi yang tidak efektif pada pasangan sehingga berujung pada kasus gugatan atau talak.

2. Penyelesaian konflik yang dilakukan oleh pasangan suami istri yang akan cerai menemukan jalan win-lose solution maupun win-win solution hanya saja, penyelesaian konflik yang terjadi pada pasangan ini berjalan dengan baik apabila masuk pada mediasi yang dilakukan penyuluh, sedangkan jika dari salah satu 
pihak tidak ingin melakukan mediasi yang di tawarkan oleh penyuluh maka yang terjadi tetap pada tujuan utama yaitu bercerai. Mediasi sangat membantu pada pasangan yang bermasalah menemukan solusi yang baik buat kedua pasangan, maka dari mediasi yang dilakukan penyelesaian konflik berujung pada win-win solution.

\section{SARAN}

Untuk mengurangi angka perceraian baik itu gugatan maupun talak pada pasangan suami istri maka perlu disampaikan saran-saran sebagai berikut:

1. Saran untuk Pasutri

a. Bagi para calon pengatin sebaiknya mengikuti syarat pranikah yang biasa dilaksanakan di KUA berupa pembekalan bagi para calon pengantin.

b. Sebaiknya pasangan suami istri dapat lebih terbuka, menghargai, dan memiliki rasa empati, mau menerima perbedaan pendapat, mendengarkan setiap saat dan saling medukung satu sama lain demi kepentingan bersama dan membangun rumah tangga yang harmonis

2. Saran untuk penyuluh atau BP4

a. Peran penyuluh yang mengatasi masalah percerian hendaknya semakin meningkatkan kemampuan dalam hal proses mediasi pada pasangan yang akan cerai, meningkatkan pengetahuan dan keterampilan yang dapat menyakinkan klien untuk terbuka pada masalah yang dihadapinya.

b. Sebaiknya penyuluh di KUA ditambah lagi khusus dalam menangani pasangan yang bermasalah yang akan berujung pada perceraian. Sebab tidak semua penyuluh memiliki kemampuan yang baik dalam mediasi klienya.

\section{DAFTAR PUSTAKA}

A.G. Lunandi. 2000. Komunikasi Mengena Meningkatkan Efeltifitas Komunikasi Antrapribadi. Yogyakarta: Kanisius.

Joseph A. Devito. 2009. The Interpersonal Communication. America: Pearson.

Joseph A. Devito. 2011. Komunikasi Antarmanusia. Tanggerang: Karisma.

Muhammad Budyatna dan Leila Ganiem. 2011. Teori Komunikasi Antapribadi. Jakarta: Kencana.

Tommy Suprapto. 2009. Pengantar Teori dan Manajemen Komunikasi. Jakarta: PT Buku Kita. 
Suciati. 2015. Komunikasi

Interpersonal (Sebuah Tinjauan

Psikologis dan Perspektif

Islam). Yogyakarta: Litera.

www.pa-slemankab.go.id. Diakses

tanggal 24-Juli-2017. 